\title{
Individual Responsibility \& Command Responsibility on Serious Human Rights Violation in Indonesia
}

\author{
Amirudin Imam Nur ${ }^{1}$, Hanafi Mursyid Wijanarko ${ }^{2}$, and Pryo Sularso ${ }^{3 *}$ iD \\ ${ }^{1}$ Universitas PGRI Madiun, Madiun, Indonesia \\ ${ }^{2}$ Universitas PGRI Madiun, Madiun, Indonesia \\ ${ }^{3}$ Universitas PGRI Madiun, Madiun, Indonesia \\ *Corresponding author: pryosularso@unipma.ac.id
}

\begin{abstract}
The wave of reform in Indonesia that was rolling in the context of overthrowing the New Order was full of abuse of power, corruption, collusion, nepotism $(K K N)$ and human rights violations. Application of the concept of a direct law enforcement system against the category of international crimes, which in the past emphasized the national justice jurisdiction (indirect enforcement system). Cases of human rights violations are very interesting, because the crimes that occur have a special condition which by experts call it a special form of political crime. The research method in this study is a normative juridical research method, which means that this research is sourced from library data. The legal issue in this research is How is the individual and command responsibilities in Serious Human Rights Violations in Indonesia. The results of this research show that Indonesia is currently under the spotlight internationally in connection with the indictment of gross human rights violations, especially in the issues of East Timor, Tanjung Priok and so on. The universal principle that it is impossible to treat gross human rights violations as "ordinary crimes" and the existence of a universal qualification regarding "crimes against humanity" requires the utilization of a special human rights court, which also contains several special criminal procedures. In accordance with the provisions of the International Criminal Code Statute (Art.l), cases which have been investigated and terminated by the country concerned will not be accepted for trial by the ICC (inadmissible). We have to show everyone that called "International Criminal Tribunal" really is complementary to the national courts.

Keywords: Individual Responsibility; Command Responsibility; Serious Human Rights Violations
\end{abstract}

$\begin{array}{ll}\text { History: } & \text { Publisher: Universitas PGRI Madiun } \\ \text { Received: February } 15^{\text {th }} 2021 & \text { Licensed: This work is licensed under } \\ \text { Accepted: February } 20^{\text {th }} 2021 & \text { a Creative Commons Attribution } 3.0 \text { License } \\ \text { Published: February } 26^{\text {th }} 2021 & \end{array}$

\section{INTRODUCTION}

Some time ago, Indonesia was under the spotlight internationally in connection with the allegations of gross human rights violations, especially in the East Timor, Tanjung Priok, Aceh DOM, Papua and so on. The wave of reform in Indonesia that was rolling in the context of overthrowing the New Order which was full of abuse of power, corruption, collusion, nepotism $(K K N)$ and violations of human rights seems to have continued, given the essence of the vision and mission of reforms far from being accomplished. Reform is basically a rational and systematic attempt to actualize the basic values of democracy. (Muladi, 1997)

The core values of democracy include consistency to always be transparent in making political decisions, upholding the rule of law, the enforcement and protection of human rights, free and impartial judiciary, creation of aspirational legal norms, law is not used as tool of political power, government that is efficient, effective and subject to the rule of law (good governance), a free press, an honest and fair election system and so on (Dieng, 1999).

The situation mentioned above is called public accountability and legal accountability must be seen as a logical consequence of the reform process and should not be seen and 
suspected as "strange thing". However, it must always be maintained so that accountability is based on certain standard recognized by civilized nations. National legal norms must always be harmonized with these standards. In this way, both the process and the results of accountability can resolve conflicts objectively.

As a nation that is part (sub-system) of global society, taking into account the dominant particularistic elements, various global trends must be seen as part of the national trend. This is especially true when it comes to human rights which cannot be ruled out, even if a country is in a state of emergency, thus it can be understood if the sources of international law will cover a broad scope such as: (a) International conventions, whether general or particular, establishing rules expressly recognized by the contesting states; (b) International custom, as evidence of a general practice accepted as law; (c) The general principles of law recognized by civilized nations; (d) Judicial decisions and the teaching of the most highly publicist of the various nations, as subsidiary means for the determinations of rules of law. (Article 38 paragraph (1) Statute of the International Court of Justice). In fact, in this case there is a more moderate view and interpret the broader global trend which includes various resolutions of UN agencies, model treaties, "code of conduct, guidelines, basic principles, safeguards, minimum standard rules" and various declarations drawn up by international bodies as well as the results of scientific meetings organized by international professional associations (Held, 1995).

Another thing that is no less interesting is the role of both national and international non-governmental organizations (NGO and INGO). In the field of human rights and democracy in particular, these organization have an important role in shaping, promoting, implementing and enforcing norms (Meron, 1989). They do not only mobilize but also give enthusiasm to accelerate, determine, and expand attention which is difficult to describe the political bureaucracy, both national and international. It is not uncommon for various policies, both national and international, to be reconsidered because of the pressure and requests of these organization. They also took the initiative to develop new international instruments, carried out campaigns and mobilized opinion formation and lobbies for government support. The facts prove that NGOs are "essential ingredients" from civil society.

There is the possibility of applying the concept of a direct enforcement system against the category of international crimes which in the past has been emphasized more on the national justice jurisdiction (indirect enforcement system) (Bassioun, 1989). These direct law enforcement practices have been carried out several times, such as the trials in Leipzig after World War I, the Nuremberg Trials and the Tokyo Courts after World War II, the trials in the former Yugoslavia and Rwanda, although they were more "ad hoc" in nature than systemic.

The framework of law enforcement, particularly in relation to the category of international crimes (international crimes), has long been a tug of war between the two jurisdictions, given their characteristics that touch not only national interests, but also international interests such as world peace and security (directly or indirectly), shocks the human conscience, inflicts more damage than a country, involves or inflicts harm on citizens of more than one state, means used to cross national borders and require cooperation between countries to overcome them. Thus, there are at least 3 (three) elements, namely (1) international elements; (2) transnational elements and (3) elements needed to overcome them (necessity elements) (Clark \& Sann, 1996).

Cases of human rights violations are very interesting, because the crimes that occur have a special nuance which by experts call it a special form of political crimes which can be in the form of crimes against the government such as illegal demonstrations, terrorism, subversion movements and so on as well as crimes committed by the authorities (crimes by government, state crimes, governmental crimes) such as law violations by intelligence 
officers (secret police), kidnapping and torture by security forces, telephone tapping and others ( Bassiouni, 1992). Thus it appears that human rights violations have a special nuance, namely the abuse of power in the sense that the perpetrators act in the context of government and are facilitated by government power (committed within a governmental context, and facilitated by governmental power) (Hagan, 1997).

The affirmation that human rights violations contain elements of "state action or policy" shows that this is closely related to the democratization process. Experience in various countries, including Indonesia shows that some individuals and groups who hold power try to maintain totalitarian rule, by combining ideology and terror (Beetham, 1999). In fact, not infrequently these two things are strengthened by positive law which is an instrument of both as a tool of power on the pretext of protecting "public orders" and economic development namely the command responsibility in cases of serious human rights violations in Indonesia. So what is the individual responsibility and command responsibility in gross human rights violations in Indonesia?

\section{MATERIALS AND METHODS}

The research method in this study is a normative juridical research method, which means that this research is sourced from library data. This research is a qualitative descriptive study (Sari). Qualitative descriptive research is research that describes qualitatively related problems (Rizka et all 2020).

\section{RESULTS AND DISCUSSION}

Law Number 26 of 2000 concerning Human Rights Courts, the serious human rights violations consist of (1) Genocide and (2) Crimes Against Humanity (Gutman \& Rief, 1999). The scope of gross violations of human rights is actually very broad. In a broad sense it also includes violations of humanitarian law, as regulated in the Hague Laws 1899 and 1907 (the Haque Laws) which regulates the methods and tools that can be used to fight and the Geneva Law of 1949 (the Geneve Law) which regulates Protection against combatants, prisoners of war and civilians as a result of war. This includes the "Additional Protocol" I 1977 which regulates victims of international armed conflict and "Additional Protocol" II 1977 which regulates victims of non-international armed conflict.

The International Tribunal's Statute for the former Yugoslavia (1993) provides that the tribunal's jurisdiction covers the following acts: (a) Grave breaches of the Geneva Conventions of 1949 berupa "wilful killing, torture or inhuman treatment, including biological experiments, wilfully causing great suffering or serious injury to body or health, extensive destruction and appropriation of property, not justified by military necessity and carried out unlawfully and wantonly, compelling a prisoner of war or a civilian to serve in the forces of a hostile power, wilfully depriving a prisoner of war or a civilian of the rights of fair and regular trial, unlawful deportation or transfer or unlawful confinement of a civilian and taking civilians as hostages". (b) Violations of the laws or customs of war berupa : "employment of poisonous weapons or other weapons calculated to cause unnecessary suffering, wanton destruction of cities, towns or villages, or devastation not justified by military necessity, attact or bombardment by whatever mean of undefended towns, villages, dwellings or buildings, seizure of, destruction or willful damage done to institutions dedicated to religion, charity and education, the arts and sciences, historic monuments and work of art and science, plunder of public or private property". (c) Genocide yang diartikan sebagai "acts committed with intent to destroy, in whole or in part, a national, ethnical, racial or religious group, as such : killing members of the group, causing serious bodily or mental harm to members of the group, deliberately inflicting on the group conditions of life calculated to bring about its physical destruction in whole or in part, imposing measures 
intended to prevent births within the group, forcibly transferring children of the group. Dalam kerangka ini pelbagai perbuatan yang dipidana tidak hanya "genocide", tetapi juga "conspiracy to commit genocide,-direct and public incitement to commit genocide, attempt to commit genocide and complicity in genocide". (d) Crimes against humanity, which includes various acts committed in armed conflict both international or national that aimed at the civilian population. These acts are: "murder, extermination, enslavement, deportation, imprisonment, torture, rape, persecutions on political, and religious grounds and other inhumane acts ".

The regulation "The International Criminal Tribunal for Rwanda" (1994) states that acts which qualify as gross human rights violations only include "genocide" and "crimes against humanity". "Crimes against humanity" has a new element that the acts committed are part of "a widespread or systematic attack against any civilian population on national, political, ethical, racial or religious grounds". In the Genocide Convention (1948) on the Prevention and Punishment of the crimes of Genocide, it is explained that genocide is an act taken to destroy all or part of a national, ethnic, racial and religious group.

In connection with the opinion that human rights violations must always be associated with armed conflict (international or internal). To explain this, it is necessary to review Article 1 " Additional Protocol to the Geneva Conventions of 12 August 1949", relating to the Protection of Victims of Non-International Armed Conflicts "which states that:

"This protocol shall not apply to situations of internal disturbances and tensions, such as riots, isolated and sporadic acts of violence and other acts of a similar nature, as not being armed conflict".

In this case what is called the "Minimum Humanitarian Standard" applies. In the Preamble to the Additional Protocol II it is stated that:

"In cases not covered by the law in force, the human persons $\sim$ remain under the protection of the principles of humanity and the dictates of the public conscience".

Thus it can be said that the category of human rights violations in the form of "crimes against humanity" is a type of international crime that can be enforced as a positive criminal law, because it has shaken the common values of the world community and disturb the peace and security of mankind. Apart from that, as an international crime, it must meet the various requirements mentioned above, namely: Serious human rights violations are Extraordinary Crimes. Gross violation of human rights is a criminal act like other crimes that are unlawful in nature and there is absolutely no justification for it. However, there are things that are special, which distinguish them from other crimes (ordinary crimes) or at least considered to be such and result in the enactment of universal jurisdiction. In addition to those already stated above, the special characteristics are as follows: (a) The prohibited conduct affects a significant international interest; (b) The prohibited conduct constitutes a egregious conduct deemed offensive to the commonly shared values of the world community; (c) The prohibited conduct involves more than one state in its planning, preparation or commission, either through the diversity of nationality of its perpetrators or victims, or because the means employed transcend national boundaries; or (d) The effect of the conduct bear upon an internationally protected interest that is not sufficient to fall either (a) or (b) above, but requires international criminalization in order to ensure its prevention, control and suppression because it is predicated on " state action or policy", without which it could not be performed (Bassioun, 1989). On the basis of the various characteristics above and based on applicable international instruments (approximately 315 multilateral instruments), it can be concluded that every international crime reflects the existence of one or a combination of the following elements:

1. International: 
a. Conduct constituting a threat to the peace and security of the international community, whether directly or indirectly; or

b. Conduct recognized by commonly shared world community values as shocking to the collective conscience of the world community.

2. Transnational:

a. Conduct affecting the public safety and economic interests of more than one state whose commission transcend national boundaries; or

b. Conduct involving citizens of more than one state (either as vistims or perpetrators) or conduct performed across national boundaries.

3. State Actions or Policy:

Conduct containing in part anyone of the first two elements but whose prevention, control and suppression necessities international cooperation because it is predicated on "state action or state policy" without which the conduct in question could not be performed."(Bassioun, 1989)

Apart from the general character above, given the qualifications of the act, there are specific things that distinguish it from general criminal acts. An example is the crime of murder, deprivation of liberty (imprisonment), torture and rape. To be categorized as a serious human rights crime in the form of "crime against humanity" must contain elements that the act is "committed as part of a widespread or systematic attact directed against anycivilian population ".:

\section{Individual Criminal Liability.}

The problem of violation is known as individual criminal responsibility. A person is deemed to have a criminal responsibility if the person concerned has committed an act which fulfills it elements of a criminal act and is against the law and don't have justification, also have the ability to be responsible, do it by mistake (intentionally or negligently) and there is no excuse for forgiveness. Furthermore, "individual responsibility" in human rights violations has a special meaning as follows:

a. Perpetrators of crimes (those who plan, mobilize, order, commit or provide assistance in planning, preparation or execution of crimes) cannot argue that their actions were carried out for the benefit of or because of a state order and assign their responsibility to the state (state responsibility) (Muladi, 2002);

b. The official position of the perpetrator cannot be used as a reason to release the person concerned from responsibility or to reduce the punishment;

c. The reason that the perpetrator commits a crime on the orders of his government or because of an leader's order (crimes by obedience) is not a justification. It may be considered as one of the reasons for reducing the crime.

d. The fact that an action was committed by a subordinate does not eliminate the responsibility of the superior, if he or she knows or has sufficient reason to know that the subordinate is committing a crime or has committed it and the superior fails to take the necessary action to prevent the act or to convict the perpetrator.

Point $\mathrm{d}$ above, what is known as "crimes by omission". In this case stated by Bassiouni as follows:

"A subordinate actor's responsibility for a violative act does not necessarily eliminate command responsibility because the latter includes failure to act. failure to prevent, and failure to punish upon discovery of the violation. But failure to act depends on knowledge and opportunity to act: 1) in the prevention of the criminal act; 2) subsequent to the act if the superior failed to supervise, discover, and take remedial action as needed under the circumstances; and 3) prosecute and, if found guilty, punish, the violator. Conversely, a subordinate actor's exoneration under the defense of "obedience to superior orders" does not 
necessarily imply that the immediate superior officer and those in the chain of command above him are criminally responsible if the order was wrongly understood or applied by the subordinate". (Bassioun, 1989)

The Rome Statute governing "the International Criminal Court" (ICC) states that:

For crimes committed by forces under his or her effective command and control or effective authority or control as the case may be, as a result of his or her failure to exercise control properly over such forces where :

a. That military commander or person either knew or owing to the circumstances at the time should have known the forces were committing or about to commit such crimes; b)Failed to take all necessary and reasonable measures within his or her power to prevent or repress their commission or to submit the matter to the competent authorities for investigated and prosecutions; c) Consciously disregarded information which clearly indicated that subordinates were commit or about to commit such crimes

\section{Command Responsibility}

The term command responsibility or superior responsibility is a broad term that includes military commanders, heads of state and government, ministers and corporate leaders. For practical needs both in the field of law and justice, for the military it is more appropriate to use the term commander's responsibility, meaning that this form of responsibility is not limited to the highest level but can also be subject to this responsibility if it is proven that it fulfills its elements.

As long as it concerns the commander's obligations (Sliedregt, 2003) (duty of commanders) to subordinates who are under their command or control, as a reference, the substance in Protocol I of the Geneva Convention is as follows (Protocol I of the Geneva Convention, 1949):

a. To prevent and, where necessary, to suppress and to report to the competent authorities breaches of the Conventions and of this Protocol;

b. In order to prevent and suppress breaches, commensurate with their level of responsibility, commanders ensure that members of the armed forces under their command are aware of the obligations under the conventions and this Protocol;

c. Any commander who is aware that subordinates or other persons under his control are going to commit or have committed a breach of the Conventions or of this Protocol, to initiate such steps as are necessary to prevent such violations and, where appropriate, to initiate disciplinary or penal action against violators thereof".

Particularly with regard to failure to do something, this is regulated in Article 86, which in essence is that violations committed by subordinates do not release the superior from criminal responsibility and disciplinary responsibility if: "they knew, or had information which should have enabled them to conclude in the circumstances at the time, that he was committing or was going to commit such a breach and if they did not take all feasible measures within their power to prevent or repress the breach". In the issue of criminal responsibility at the international level there are many discussions about what is called "criminal responsibility of states". For a long time, this principle has been accepted both as a principle and as a part of international jurisprudence, although as positive law it has received little attention (the responsibility of state in international law had received little systematic attention) (Eagleton, 1988). The difference of opinion revolves around the qualifications of acts committed by the state, especially in international public law. Is it included in the framework of criminal law (penal prosecution) or civil law (tort/liability). In this case, what is important to note is "the principle of proportionality". Likewise, sanctions in the form of "reparation" or "redress" with the mechanism need to be considered. 
Acceptable responsibility is the criminal responsibility of a high ranking official. However, the relationship between international criminal law and state responsibility remains uncertain. In most cases, individual acts involve both criminal responsibility and international responsibility by the state, however, both are considered separately. Logically, if the organs and state officials did something wrong, then the state should also be held responsibility. From a legal theory point of view, it can be justified in connection with the development that "corporations" can become subjects of criminal law (collective responsibility) on the basis of the principle of "vicarious liability" and the principle of "functional behavior".

The developing opinion hopes that individual responsibility for crimes against humanitarian peace and security does not eliminate the state's responsibility under international law, whether active or omissionous (ILC, 1981). Ad Hoc Human Rights Court In Indonesia has implemented the responsibility of this commander in adjudicating cases of gross human rights violations in East Timor.

\section{Legality Principles And Prohibition Of Retroactive Of Law}

Legality principle grew to become a fundamental principle of criminal law in most criminal justice systems in the world starting in the late 1800 s, as a result of changes in political thought in Europe and the philosophy of law that developed during the Age of Enlightenment.

These principles consist of: (1) nullum crimen sine lege (no crime without a law): (2) nulla poena sine lege (no sanction without a law); and (3) nulla poena sine crimine (no sanction without crime). This principle also includes derivative principles such as "nullum crimen sine lege praevia" (no crime without the previous law) and "nullum crimen sine poena legal!" (no prearranged crime without punishment). Another related principle is the prohibition to apply "ex post facto criminal law" and its relation to retroactive application of criminal law and criminal sanctions.

Even though the legality principle is related to the legislative constraint, it also touches the rules regarding judicial interpretation, namely the prohibition or restriction on the use of analogy. On various occasions, scholars have also emphasized the application of the principle of "lex certa" (laws must be formulated as clearly and sharply as possible and must be trusted). In this case, two functions are related at once, namely: (1) the function of protecting (protecting the people from the exercise of unlimited power); and (2) instrumental function (within the limits stipulated by law, the exercise of power by the government is expressly permitted).

Overall, the objectives of the legality principle are (1) strengthening legal certainty; (2) creating justice and honesty for the accused; (3) make the "deterrent function" effective from criminal sanctions; (4) prevent abuse of power; and (5) strengthening the application of the "rule of law" (Schaffmeister et al 1995).

The application of the legality principle varies from country to country depending on whether the government is democratic or tyrannical. The variations also depend on the family law followed. The Continental European system tends to apply the legality principle more rigidly than it does in countries that adhere to the Common Law system, because in Continental European countries the legality principle becomes a tool to limit the power after the French Revolution. In Common Law countries, the legality principle is not that prominent, because the principles of the Rule of Law have been achieved with the development of the concept of "due process of law" which is supported by good procedural law (this has even started in 1215 with the formulation of Magna Chart). Analogy is not only permissible, but is even the basis for the renewal of Common Law.

The former Soviet Union (Marxist Socialism) before 1976 implemented "Socialist Justice" which rejected the legality principle, especially for crimes that were categorized as 
"socially dangerous", both related to criminal and criminal acts. Since 1976 the former country has adapted to Western European countries. Although this principle has been accepted as the "general principle of law" in Western Europe and Latin America, in Common Law countries and Asian African countries that were not colonized by Western countries, this principle is still widely abused.

The application of the legality principle is not the same as between national law and international law, because in addition to international law originating from products of "customs and practices of states", it also comes from "certain basic national principles".

Even though each national law has its own uniqueness, what stands out from international criminal law is the criminalization process that occurs far from legislative policies and standards. International criminal law is more conventional in the form of hundreds of instruments, which are developed by international organizations which are heavily influenced by factors of the political environment. This is often without consistent and uniform design techniques, so that it does not meet legality standards.

Designers are generally diplomats who are often not experts in international criminal law and / or criminal law in comparing and working only on an "ad hoc process" basis. What should be noted is that the formulation of the norms is not directed to be applied to individuals through international criminal courts. Thus it is more of an obligation for countries to use it as material for the reform of their respective national criminal laws.

The definition of international crimes is usually very general and broad. In fact, they often forget the elements of criminal acts and criminal responsibility as stated in the general section of the national criminal law. It is often seen that international criminal law also does not regulate criminal sanctions. Therefore, international customary law practice does not include the principle of "nulla poena sine lege". There is also an articulation of the principle of "nullum crimen sine lege" to "nullum crimen sine iure" (no crime without law) which is the "core" of the legality principle in international criminal law.

This can be seen from various international criminal law conventions which are also manifestations of international customary law practice. In this case, it is possible to use analogy in relation to the national law of the country concerned. The principle of retroactive prohibition is also known in international criminal law as a result of the interaction between treaties and diplomatic and judicial practices.

Especially regarding crimes against humanity as a form of gross violation of human rights, if it is applied retroactively, it is considered not to violate the standard of legality principles in international criminal law because the crime is merely an expansion jurisdiction (extension jurisdiction) of war crimes (an outgrowth of war crimes) and accepted as international customary law and has been decided by an ad hoc international court.

What was done by the International Military Tribunal in Nuremberg would not set a precedent, because it did not create new laws, but simply a matter of applying the laws already in the International Agreement on "war criminals". Another argument that arises is related to the maxim "nullum crimen sine lege" which is actually not a limitation of sovereignty, but is a "principle of justice". It is unfair if the guilty are left unpunished.

In international criminal law the development of the legality principle has occurred through various international instruments since 1946. These various instruments link the legality principle not only to national law but also to the provisions of international law, when the act is committed, "the general principle of law is recoqnized by the community of nations" (Bassiouni, 1992). This needs to be emphasized because of the ICC Statute (Art.21 and 22) which prohibits the retroactivity of a provision (non-retroactivity - ratione personae).

Since the Nuremberg and Tokyo trials, several countries have tried cases of "crimes against humanity" without questioning the principles of legality, such as Israel in the Adolf 
Eichmann case in 1960, France in the Barbie case in 1988, Canada in the Imre Finta case in 1989, Rwanda in 1993 and Former Yugoslavia in 1994.

\section{Establishment Of An International Criminal Court}

The effort to establish an International Criminal Court is a topic that was intensively discussed in a symposium organized by "the International Association of Penal Law" within the framework of "the Fifth UN Congress on the Prevention of Crime and the Treatment of Offenders" held in Geneva on September $5^{\text {th }}$ 1975. At that time a historical review is discussed that the first proposal was submitted in 1872 .

Further initiatives were presented by the "International Law Association" (ILA) at the ILA Congress in Belgrade in 1980 and the International Criminal Court has jurisdiction over "genocide" and "war crimes" under the Geneva Conventions. The existence of this Court is intended to prevent possible interference on the basis of state sovereignty and the need to coordinate the struggle and cooperation against international crimes. On the basis of the Principle of Sovereignty, various countries, especially socialist countries, reject the idea of forming a supra-national institution and give priority to ad hoc institutions rather than permanent ones.

In fact, Britain and America initially rejected this idea and the various countries that supported the establishment of the International Criminal Court required a 'Code of Crimes against the Peace and Security of Mankind'. The existence of the International Criminal Court (ICC) is expected to guarantee an objective trial and not partiality which is difficult to achieve, in addition to avoiding different convictions between countries, in the 1993 ICC draft court jurisdiction covers three types of crimes: (1) crimes under the general international law; (2) crimes under a list of treaties in force (the Genocide Conventions, the Four Geneva Conventions 1949 and the First Protocol of 1977, and the various terrorism conventions directed at hijacking, hostage taking etc.), and (3) a further category of crimes under national law giving effect to what were described as "suppressions conventions".

The jurisdiction of the ICC in 1994 was changed and covered four categories of crimes: (1) the crime of genocide; (2) the crime of aggression; (3) serious violations of the laws and customs applicable in armed conflict; (d) crimes against humanity. This jurisdiction was not changed in the 1998 Rome Statute. This court was formed after being ratified by 60 countries with the hope of limiting the practice of "impunity" for serious international crimes, providing justice to victims and preventing further atrocities (Steiner and Aston, 1996).

The final agreement on the ICC (Statute for International Criminal Court 1998), among others, allows the ICC based in The Hague to carry out investigations and prosecute "genocide, crimes against humanity, war crimes (whether committed in international or non international conflicts) and crime of aggression. "which the national government failed to do. The public prosecutor can take the initiative to investigate the indictment when it receives information from the victim and other reliable sources and brings the case to the ICC, without requiring a complaint (referral) from the state party. Likewise, the proposal to grant veto power to the 5 permanent members of the UN Security Council regarding court procedures cannot be accepted. The rights of suspects and defendants are expressly guaranteed. Likewise, the provisions regarding witness protection and their role in events at the ICC.

Basically, there is a principle that the ICC is complementary to the national criminal jurisdiction. In this case the ICC can adjudicate (admissible) if the country concerned is unwilling or unable to carry out investigations and prosecutions and in the end decides not to sue (decided not to prosecute). "Unwillingness" is a reflection of the impression that the measures taken at the national level are intended as a shield against the jurisdiction of the ICC, and unjustified delay and not being conducted independently or impartiality. Inability is 
associated with the impression that the national justice system "collapses or unavailability" is either total or substantial.

In addition to the complementary principle above, another interesting principle is the inherent / automatic principle concerning the authority of the prosecutor who because of his position (proprio motu) takes the initiative to conduct investigations without the approval of the state parties and the principle of nebis in idem where the ICC has the authority to override the principle of nebis in idem if according to his evaluation the national court is carried out irresponsibly as described above.

\section{CONCLUSION}

Currently Indonesia is under the spotlight internationally in connection with the indictment of gross human rights violations, particularly in the East Timor, Tanjung Priok and so on. In this case, in accordance with the above standards, in particular the universal principle that it is impossible to treat gross human rights violations as "ordinary crimes" and the existence of universal qualifications regarding "crimes against humanity" requires the utilization of a special human rights court, which also contains several criminal procedures which are special.

The DPR's rejection of Perpu No. 1 of 1999 as the implementation of Article 104 of Law no. 39 of 1999 requires the existence of a new Law on Human Rights Courts, which must comprehensively accommodate international aspirations as well. The Indonesian nation must demonstrate to the international community and the national community that we are willing and able to resolve it through an independent and impartial Indonesian court, in accordance with international legal standards. The prosecution process will be carried out carefully (diligently prosecuted) which always respects the rights of the accused, victims and witnesses.

If these standards have been implemented, then in accordance with the provisions of the ICC Statute (Art.l), cases that have been investigated and terminated by the country concerned will not be accepted for trial by the ICC (inadmissible).

We have to show everyone that the so-called "International Criminal Tribunal" really is complementary to the national courts. This also shows the outside world that the Indonesian people are fully aware that gross human rights violations must be condemned by all mankind, all countries and also the United Nations. Furthermore, we are also aware that what is called human rights is basically an integral part of democracy.

\section{ACKNOWLEDGMENTS}

I say thank to God, my family, Universitas PGRI Madiun, and all friends who support me to finish this research.

\section{References}

(1949). Protokol I Konvensi Jenewa. Jenewa.

Bassioun. (1989). International Criminal Law ( Crmes). New York : Transnational Publ Inc.

Bassiouni, M. C. (1992). Crimes Against Humanity in International Criminal Law. London: Martinus Nijhoff Publisher.

Beetham, D. (1999). Democracy and Human Rights. Polity Press.

Clark, R. S., \& Sann, M. (1996). The Prosecution of International Crimes. London: Transaction Publ. 
Dieng, A. (1999). The Rule of Law in a Changing World. ICJ.

Gutman, R., \& Rief, D. (1999). Crimes of War : What the Public Should Know. New York: WW Norton Company.

Hagan, F. E. (1997). Political Crime, Ideologi and Criminality. Singapore: Allyn and Bacon.

Held, D. (1995). Democracy and the Global Order. Langley : Polity Press.

ILC. (1981). Report on the draf Code of Crime against the Peace and security of Mankind. ILC.

Meron, T. (1989). Human Rights and Humanitarian Norms as Customary Law. London: Clarendon Press-Oxford.

Muladi. (1997). Politik dan Sistem Peradilan Pidana. Semarang : BP UNDIP.

Muladi. (2002). Pengadilan HAM dan Prinsip-prinsip Pengadilan Bagi Pelanggaran HAM Berat di Indonesia. Semarang: UNDIP.

Rizka, Pradnyawan, S. W., \& etall. (2020). Visum Et Repertum in the Evidencing Process of Rape in Indonesia. Indian Journal of Forensic Medicine and Toxicology, 14(2), 167-171.

Sari, S. D. (n.d.). Perlindungan Hukum Warga Negara dalam Praktek Medical Aesthetic Tourism. Jurnal Global Citizen: Jurnal Ilmiah Kajian Pendidikan Kewarganegaraan, $8(2), 9-16$.

Sliedregt, E. (2003). The Criminal Responsibility of Individuals for Violation of IHL. TMC Asser Press. 